\title{
A multi-level analysis of mainstream agriculture's impact and development of alternative agriculture in Thailand
}

\author{
T. Kerdnoi ${ }^{1,2}$, T. Prapamontol ${ }^{2} \&$ S. Prabudhanitisarn ${ }^{3}$ \\ ${ }^{I}$ Sustainable Land Use and Natural Resource Management PhD Program \\ (SLUSE), Faculty of Social Sciences, Chiang Mai University, Thailand \\ ${ }^{2}$ Research Institute for Health Sciences (RIHES), Chiang Mai University, \\ Thailand \\ ${ }^{3}$ Faculty of Social Sciences, Chiang Mai University, Thailand
}

\begin{abstract}
With the global market of vegetable and fruit production, there is also a broadened use of agrochemicals in Thailand. The impact of agrochemicals is reported to cause many environmental problems, such as soil degradation, sediment and water pollution. Moreover, these problems affect the communities, for example the local economy, personal health and family relations. Although there are several initiatives from both governmental organizations and nongovernmental organizations to promote alternative agriculture for safety of humans and the environment, a resolution to this problem is still far away and one must struggle with the dominant regime of mainstream agriculture. This paper reviewed the impact of agrochemicals on the environment and communities in Thailand in the past decade. The purpose is to reflect the power of mainstream agriculture on society and communities.

Keywords: a multi-level analysis, mainstream agriculture's impact, Thailand.
\end{abstract}

\section{Introduction}

Thailand has been an agricultural country for decades though few industries have been moving in some parts of the country. Agrochemical-based farming is the main cultivation whereas very small proportion is organic or non-agrochemicalbased farming. Recently, there are some efforts try to fight with the huge regime 
of power in mainstream agriculture production for safer food production. The dominant power is very strong and embedded all over the socio-technological regime. In this paper, we review the socio-technological regime of mainstream agriculture in Thailand, which is embedded throughout the society and economic policies of production, consumption and impact on the environment and communities. Although the farmers and some actors' network have been struggling to change toward safer production and consumption, this movement has not grown enough to fight against the mainstream agriculture. So this is the starting point of view by using the Multi-Level Perspective (MLP) from Sustainability Transition Theory published by Smith [1] and Geels and Schot [2] for analyzing the phenomena of Thailand agriculture.

\section{Socio-technological regime of mainstream agriculture in Thailand}

Thailand's agricultural system transitioned from subsistence agriculture to commercial agriculture, after the green revolution era to produce food to meet the growing needs of an increasing world population. By this way, the country has developed the technology and the use of chemicals in agriculture by the mechanisms of government policies and support from international organizations, entrepreneurs and businessmen [3]. The various processes of transform agriculture are as summary following:

1) Introduction of a new type of seed plants replacing indigenous species and the use of chemical pesticides and chemical fertilizers.

2) Promoted trade within the market system and capitalist export through middlemen. Marketing system of the chemical business.

3) Building up infrastructures for irrigation, dam, road, rail freight and raw materials into the community.

4) Providing financial support such as loans and grants from international organizations into the communities by setting up Bank for Agriculture and Agricultural Cooperatives (BAAC), Thailand for loan money sources to farmers

5) Enhance and develop new farming knowledge basing on agrochemicals to farmers under various activities such as, set up the unit in the Ministry of Agriculture and Agricultural Extension and personals for promoting the agrochemicals widely used. Developed integrating production, focus on marketing and export markets. Recently, contract farming production is established and widely strengthening. The amount of contract farming company grew together as the use of agrochemicals increased. And instructed institutions of modern agricultural technology to transfer academic and research to distribute all of innovation to the community.

It is said that all of those driven activities and sectors together with NSDB plan for commercial production and export targets for access to foreign countries 
and rely on economic growth (in terms of GDP) as an indicator of development depending on standards of western countries. It can be said that the government's promoting the use of chemicals has been influenced by the manufacturers and corporations who import these chemicals $[4,5]$. It was shown that the factors of production, such as the import of agrochemicals in Thailand increases every year. Statistics have shown the import of chemicals and hazardous materials in agriculture in Thailand in the year 2005 to 2009: import volume average of 105,923 tons per year, worth an average 11,168 million baht compared to the year 1996 the amount of just 25,540 tons. Hence from 2005 to 2009, amounts of imported agrochemicals have been increased up to 54.9 percent [6]. The use of agrochemicals at the community level is dramatically increased being ineffectively controlled or supervised. Many pesticides have been applied intensively in order to improve both quality and quantity of crop production [7]. This is combined with the distribution of chemical business, and promoted thoroughly from the city to shop in the community and direct sales [8].

\subsection{Impact of mainstream agriculture}

The mainstream agriculture and numerous used of agrochemicals have had a wide impact all over the country, with the large amount of agrochemicals that spread in the air, soil, water resources and agricultural crops [9]. They contaminated in food and affected on the health of farmers, consumers and ecosystems [10]. Moreover, there was great impact on the social and communities, as following:

\subsubsection{Debt accumulation}

Due to the unfavorable manufacturing and commercial system, the farmers have to rely on capitalist middlemen and technology from outside the communities. It caused them to accumulate debt which related from overuse of fertilizers and pesticides to fight with land degradation, increase of weed, insects, and diseases [11]. The more that they have to invest in fertilizers and chemicals, the more they must draw debt from the capital, because of decreased product price and low income-to-expenditure ratios. Moreover, the farmers tend to have little financial knowledge for managing their farm production and crop by themselves $[12,13]$.

\subsubsection{Impact on human health, society and culture}

Farmers in mainstream agriculture have to work hard to get enough production and family income and also hope to pay the debt. Frequently, a farmer's time is dedicated to cultivation and maintaining quality of production. Even among farmers who engaged in contract farming, they must follow the strict requirements of the company [14]. This manner of working causes stress, and combined with hard work and exposure, it causes hardships for the farmer's health.

For example, farmers who worked in agriculture (as well as general consumers) reported acute and chronic effected result associated with the use of pesticides, such as dizziness, nausea, numbness [15-18]. Reporting detected levels of contamination of pesticides from blood and urine in few groups of 
population have shown the accumulation of chemicals in human body as a possible health risk due to chronic and long term exposure [19, 20]. Additionally, is also associated with a decrease of thyroid hormone level in cord blood of newborns [21].

\subsubsection{Impact on social and family relations}

Having to spend time with the farm in action through mainstream production, farmers do not have enough time with family and community activities as in previous eras. Additionally, it has changed the culture of production complementary support employment as a kinship. Traditional practices in agriculture systems from the past disappear, causing the collapse of traditional agriculture and local knowledge [14, 22].

\subsubsection{Impact on ecosystem}

The intensive nature of growing the same crops on the same land causes serious problems with the ecosystem and land degradation, natural resources, local vegetation [23] and it has resulted in the outbreak of insects, pests and weeds [24]. Moreover, residues of herbicide are contaminated in drinking water in the vegetable farm area [25]. Residues of pesticides are found in vegetable and fruit samples in many kinds of domestic markets [26-29].

\section{Emerging trend}

Since numbers of information from the impact of agrochemicals are presented in Thai society, there are many groups and networks of people come to fight for safe food production. They are especially from academia, private organizations (NGOs), government organizations and activities groups who are concerned on health and environment. They try to create various forms in society; such as rejecting toxins in food, or anti-trade barriers in the world. Other initiatives include promotion of organic agriculture by NGOs, campaigning on environmental and health, as well as researching the impact of chemicals on health and the environment. It affects the social to ask for the safety production. Consumers are more alert, and may finally begin to affect the government and food manufacturing production.

\section{Socio-technical configuration of alternative agriculture}

With such deep-rooted problems, it has been an effort to struggle against the advancement of agrochemicals by promoting alternative farming in all regions of the country. Some examples are the agriculture network in the Northeast Region [30], the Green Net cooperative in Bangkok, and the organic cooperative in Chiang Mai Province. Moreover, there are academics and researchers who are working to promote safe agriculture. For example, in Chiang Mai University, there is a group working to encourage farmers to grow pesticide-free vegetables, integrated farming and organic farm for the safety of food and health [31]. In summary, the various processes are as following: 
1) Strengthening the farmer's capacity to manage the farm, marketing and product management.

2) The study of the impact of chemicals on health and the environment, and publishing the results to the society and the community.

3) Campaign for food safety, such as drawing social attention by multimedia, building up more space for distribution of free chemicals agricultural products, organizing more organic farmer groups and more space for selling in the community and the city, setting up shelf in markets and shopping malls. All these activities are participated by various sectors such as public health organization, educational, NGOs and private business.

The struggle of alternative agricultural groups has to combat the mainstream agriculture. The big problem is that the farmers are accustomed to producing with agrochemicals as their life-long habit. They have to face with many problems that they cannot manage such as insects, the revenue expenditure and debt problems, the needs of diverse consumer products, the problems of product management and marketing. However, they can broaden areas of production and distribution of alternative agricultural products, such as organic and chemicalfree agriculture. Through these strengthening of a network, they can continuously sell their products with consumers regularly. However, the phenomenon has not grown enough. The supporting reason is based on the amount of imported agrochemicals and increased health impacts as shown. Additionally, for the area of mainstream agriculture compared to areas of reported organic farming; which has only 0.12 million rais [32] from the farmland of 122.2 million rais of the country [33].

Rai: a measurement system of land; 1 rai $=1,600$ square meters $/ 0.14$ hectare.

\section{Conclusion}

The phenomenon that occurs with the mainstream of Thai agriculture is closely linked with strong capitalist states and transnational interests to regimes that cover technical, social life, production and consumption in a society life, despite the problems and impacts caused by widespread social and environmental communities. Although there are many actors to fight for a new path way, but the formation of such groups is still a network effect or niche. The interest has been supported by consumer groups and agencies in the promotion of various public sector and private sector. But there is not enough power to fight with the growth of agricultural developments in the dominant regime. Although, the demand for safe products such as food safety in international markets, domestic markets are very volatile. It is a question that the past described are mostly focus on the micro level, such as the potential impairment of the production of various marketing and promotion initiatives and the attempt to add capabilities does not lead to growth as expected. Thus, because of the mainstream agriculture are on the macro level. It may become a limitation of the development path way of 
alternative agriculture. A multi-level analysis from Theory of Sustainability Transition will be applied for the potential of the next study.

\section{Acknowledgements}

We thank all who had studied and written the impact of mainstream agriculture and actors' network who has struggled for alternative agriculture. We hope this reviewed will be the path way to develop for the safety of food and environment.

\section{References}

[1] Smith A, Green niches in sustainable development: the case of organic food in the United Kingdom Environment and Planning C: Government and Policy 24 (3) pp. 439-458, 2006.

[2] Geels, F.W., Schot, J. Typology of sociotechnical transition pathways, Research Policy 36 pp. 399-417, 2007.

[3] The National Economics and Social Development (NSDB) Plan, 19611991.

[4] Ravenswaay, E. van Skelding, P.T. The Political Economics of risk-Benefit Assessment: The Case of Pesticides. American Journal of Agricultural Economics, Vol. 67. pp. 971-977, 1985.

[5] Praneetwatanakul, S., Policy of Pesticides in Thailand, Thai Public Health Foundation and Thai Health Promotion, 2005. www.thaienviforum.net

[6] Office of control plants and agricultural material. Department of Agriculture, 2009.

[7] Unprasert, W. Community and Agrochemical Use. Health Systems Research Institute (HSRI), 2003.

[8] Hnongchang, P. Marketing Hazardous: Promotion of selling pesticides in the area base. Health Systems Research Institute (HSRI), 2005.

[9] Tinnaluck, Y., Knowledge Creation and Sustainable Development: A Collaborative Process between Thai Local Wisdom and Modern Sciences. THESE, Sciences de l'Information et de la Communication Université de Poitiers ICOMTEC, 2005.

[10] Prapamontol, T. et al., Scoping for Assessment of Health Impact among Farmers from Using Agrochemicals in Chaing Mai and Lamphun Provinces, 2004.

[11] Chanjom, C. et al. Platform of Solving Debt of Baan SamKha Community Huaseu Subdistrict Maetha District Lampang Province. Thailand Research Fund, 2004. Chiang Mai: Regional Center for Social Science and Sustainable Development Faculty of Social Sciences Chiang Mai University, Imprint 2003.

[12] Chaiwan, N., Thanasarn, T., Tuminmul, S. Sustainable agricultural research process. With small farmers in the North: Final research report. Thailand Research Fund, 2000.

[13] Khampang, P. Agriculture for sustainable livelihood in farmers' significance and conditions: a case study of an organic farming group's 
members in Tambon Mae Tha, King Amphoe Mae On, Changwat Chiang Mai. Imprint Chiang Mai :Graduate School Chiang Mai University, 2005. Markets. Master of Public Health. Chiang Mai University Chiang Mai Thailand. 2001.

[14] Sangarak, P. Transformation of commercial to alternative agricultural systems at community level: a case study of Mae Lo watershed communities, Mae Rim and Mae Taeng Districts, Chiang Mai Province. Master of Sciences thesis: Land use and national resource development, Faculty of Social Sciences Chiang Mai University Chiang Mai Thailand

[15] Panuwet, P., Prapamontol, T., Chantara, S., Olsson, A.O., Barr, D.B. A pilot survey of pesticides specific urinary metabolites among Farmers in Chiang Mai highland agriculture area, Chiang Mai University Journal, 3 (1), pp. 25-34, 2004.

[16] Panuwet, P., Prapamontol, T., Chantara, S., Bar, D.B. 2008b. Urinary pesticide metabolites in school students from northern Thailand. Int. J. Hyg. Environ. Health (article in press)

[17] Kerdnoi, T., Prapamontol, T., Udomvong, N., Puangmanee, J., Tothirakul, S., Taejareonkul, S., Rattanasri, Inseeard, S. Knowledge and Risk Perception on Pesticide Exposure among Northern Thai Agricultural Labours. Poster presentation at International Conference on Environmental Epidemiology \& Exposure, Science, Population Diversity, Caution and Precaution, September 2-6, 2006, Paris. Abstract Book, Poster No. p-378, page 273.

[18] Prapamontol, T., Mevatee, U., Mangklabrucks, A., Udomvong, N., Kaewthummanukul, T., Sriboonruang, S., Nimsakul, S., Kingkeow, C., Hongsibsong, S. Multiple Pesticide Exposure and Chromosome Aberrations among Orange Farmers from Northern Thailand. Poster discussion presentation at International Conference on Environmental Epidemiology \& Exposure, Science, Population Diversity, Caution and Precaution, September 2-6, 2006, Paris. Abstract Book, Poster Discussion No. SM1PD-01, page 47.

[19] Tanyaporn Kerdnoi Perception and Practice on Using Pesticide of Farmer: A Case Study in Banphapai Tambon Mae Pong Amphoe Doi Saket Changwat Chiang Mai Thailand Research Report. 2004.

[20] Prapasri Tiputai. Impact on People's Health from pesticide use in Orchard, Moungyai Subdistric, Wiang Kaen District Chiang Rai Province. Master of Public Health. Chiang Mai University Chiang Mai Thailand. 2003.

[21] Asawasinsopon, R., Prapamontol, T., Prakobvitayakit, O., Vaneesorn, Y., Mangklabruks, A., Hock, B., Plasma levels of DDT and their association with reproductive hormones in adult men from northern Thailand. Sci Total Environ. 2006 Feb 15;355(1-3):98-105

[22] Nartsupha, C. The Thai Village Economy in the Past. English Translation by Chris Baker and Pasuk Phongpaichit. Chiang Mai: Silkworm Books, pp. viii, 131. 1999.

[23] Santasombat, Y. Biodiversity local knowledge and sustainable development, 2003. 
[24] Panyakul V. Sustainable Agriculture future of agricultural. Bangkok: Papiruse printing, 2001.

[25] Prapamontol, T., Byanju, R. M., Wiboonnattakul, K. Final Report, The study of human exposure to pesticides and other toxic substances in the northern Thai population: II Herbicide contamination in potable water in Sarapee District, Chiang Mai Province, Research Institute for Health Sciences, Chiang Mai University, 1999.

[26] Russamee, O., Level of Pesticide Residues in Vegetables from Chiang Mai Municipality Markets. Master of Public Health. Chiang Mai University, Chiang Mai Thailand, 2001.

[27] Atisook, K., Sungwaranon, B., Lertreungdej, Y., Jongmeevasana, P., Payanant, T. and Chaipolngam, R., Pesticides residue in food monitored in Thailand, 1999-2003. Paper read at Uses and Effect of Pesticide in South East Asia Symposium. December 11-13, 2003. Bureau of Quality and safety of Food. Department of Medical Sciences. 2003.

[28] Sribandhit, P et al. Graduate School, Chiang Mai University 1999.

[29] Surat Hongsibsong et al, Survey of Pesticide Residues in Cabbages and Kale from Traditional wet markets during a High-Risk Season, Chiang Mai City, 2007.

[30] Gopal, B. Thapa, Rattanasuterakul, K., Adoption and extent of organic vegetable. 2010.

[31] Phoungmanee, J. Analysis of possibility on produce pesticides free vegetable a case study the development and extension project of pesticides free vegetable production in farmers' group of Mae Rim District, Mae Tang District, San Sai District and Maung District, Chiang Mai Province .Faculty of Agriculture, Chiang Mai University, 2008.

[32] Green Net and Earth Net Foundation, 2007 http://www.greennet.or.th/

[33] The National Statistical Office, 2010 